\title{
EHMTI-0088. Prediction of treatment response in chronic daily headache patients (a prospective study)
}

\author{
V Golovacheva*, V Parfenov, G Tabeeva
}

From 4th European Headache and Migraine Trust International Congress: EHMTIC 2014

Copenhagen, Denmark. 18-21 September 2014

\section{Introduction}

The prevalence of chronic daily headache $(\mathrm{CDH})$ is $4-5 \%$ in general population. In headache clinics about $40 \%$ patients have $\mathrm{CDH}$ and $50-82 \%$ of them overuse acute drugs. Combining pharmacological and behavioural therapies can increase effectiveness of treatment, but predictive factors of treatment response are still discussed.

\section{Aims}

To examine predictive factors of treatment response for patient with $\mathrm{CDH}$

\section{Methods}

35 patients with $\mathrm{CDH}$ in age from 23 to 78 years were included in the study. All patients were treated by pharmacological therapy and cognitive-behavioural therapy. Patients with medication-overuse headache $(\mathrm{MOH})$ underwent withdrawal therapy. Prospective analysis of clinicalpsychological characteristics was performed at the end of 1 and 3 months of treatment.

\section{Results}

$40 \%(\mathrm{~N}=14)$ of patients were classified as having chronic migraine $(\mathrm{CM}), 25,7 \%(\mathrm{~N}=9)$ had chronic tension-type headache $(\mathrm{CTTH}), 31,4 \%(\mathrm{~N}=11)$ had CTTH and episodic migraine, 2,9\% $(\mathrm{N}=1)$ had hemicrania continua. $62,9 \%(\mathrm{~N}=22)$ patients suffered from comorbid psychiatric conditions. Of those, $15,6 \%(\mathrm{~N}=5)$ had mood disorder, $17,1 \%(\mathrm{~N}=6)$ - anxiety disorder, $14,3 \%$ $(\mathrm{N}=5)$ - personality disorder and $17,1 \%(\mathrm{~N}=6)$ suffered from somatization disorder. $60 \%(\mathrm{~N}=21)$ of participants experienced at least $50 \%$ reduction of headache

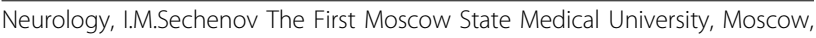
Russia

(c) 2014 Golovacheva et al; licensee Springer. This is an Open Access article distributed under the terms of the Creative Commons Attribution License (http://creativecommons.org/licenses/by/2.0), which permits unrestricted use, distribution, and reproduction in any medium, provided the original work is properly cited. frequency after 3 months of treatment. Predictive factors of poor treatment response were: 1) certain psychiatric disorders (mood disorder, somatization disorder, schizoid personality disorder); 2) duration of $\mathrm{CDH}$ is more than 5 years; 3 ) out of employment.

\section{Conclusion}

Predictive factors of poor treatment response are mood disorder, somatization disorder, schizoid personality disorder, more than 5 -years duration of $\mathrm{CDH}$ and out of employment.

No conflict of interest.

Published: 18 September 2014

doi:10.1186/1129-2377-15-S1-D23

Cite this article as: Golovacheva et al: EHMTI-0088. Prediction of treatment response in chronic daily headache patients (a prospective study). The Journal of Headache and Pain 2014 15(Suppl 1):D23.

Submit your manuscript to a SpringerOpen ${ }^{\odot}$ journal and benefit from:

- Convenient online submission

- Rigorous peer review

- Immediate publication on acceptance

- Open access: articles freely available online

- High visibility within the field

- Retaining the copyright to your article

Submit your next manuscript at $>$ springeropen.com 